\title{
R wie Randy Newman oder Musik aus Hollywood im Ops
}

\section{Dominik Heim}

PD Dr. med., Klinik Hohmad, Thun, Mitglied FMH

Über Musik im Ops ist man sich uneins. Es müsse etwas Eingängiges sein, so nach dem Motto «alle können mitsingen», zum Beispiel also "Alperose» (das schliesst aber die des Schwiizerdütsch Nicht-Mächtigen aus). «Rondo Veneziano» hatte eine gute Zeit bei den Gefässchirurgen, man vermutete eine musikalische Harmonie im Moment, wo aus dem good bypass ein goodnight pass wurde. Differenziert muss Rock betrachtet werden: «Rock music (specially Australian music rock music) appears to have detrimental effects on surgical performance. Men are advised not to listen to rock music...» [1]. Ist irgendwie beim Gedanken an AC/DC nachvollziehbar. Und etwas Ruhigeres?

\section{Auch wir Ärzte sind in seinen Texten:}

Wir sind «he doctors, she doctors, knee doctors und tree doctors".

"When people listen to my music, I'd like them to relax» sagt Randy Newman im Interview mit der amerikanischen Musikplattform Pitchfork [2], schränkt dann aber grad ein "But I just can't make myself do anything that you could just put on while eating a Baby Ruth and drinking a Coke.»

Randy Newman, 74-jährig, amerikanischer Komponist und Songwriter: Neun Jahre nach seinem letzten Studioalbum kommt «Dark matter». Er, gerne als Liebling der Intellektuellen apostrophiert, auch zweifacher Oscargewinner für Filmmusik, unterlegt seine ironischen, bissigen, aber auch melancholischen Texte mit üppigen Orchesterarrangements aus Ragtime, Swing und eben Hollywoodscher Filmmusik, dann wieder sitzt er ganz allein am Klavier, spielt Rock und Blues. Seine Lieder berühren: «Make sure he sleeps in his bed at night, don't let him sleep in that chair», sagt die sterbende Mutter zu ihren Kindern, meint dabei ihren Mann und erklärt: "I was young when we met and afraid of the world, now it's he who's afraid and I'm leaving." Das ist Randy Newman! Ferdinand Hodlers Bild von der sterbenden Valentine Godé-Darel, der Mutter seiner Tochter Paulette, kommt einem in den Sinn. Und, um beim «dark» zu bleiben, «You want it darker?» fragte
Leonard Cohen vor einem Jahr auf seiner letzten CD, antwortete "we kill the flame», und kurz darauf erlosch die Flamme.

Auch die Politik findet ihren Widerhall in seinen Texten. Das Lied über Trump hat er nicht veröffentlicht (das tat Roger Waters (Kolumne «F wie ... »). Kritisiert werden die Zustände in USA trotzdem in «Wandering boy", dem Lied über einen, der vielleicht Präsident hätte werden können, doch der "a tough time with heroin and a lot of other things" hatte und dann das "falling of the grid into the big hole» erlebte. In besagtem Interview [2] erklärt Newman "There's no net in this country. In Sweden, you can't get down there to the gutter. But you can here.» Dafür kriegt Putin sein Lied, wird charakterisiert als "he can power a nuclear reactor, with the left side of his brain" (immerhin hat er im Gegensatz zu seinem amerikanischen Kontrahenten noch eines) und wenn er sein Hemd auszieht, dann "he drives the ladies crazy.» Aber ganz klar: «He's a bad guy.»

Auch wir Ärzte sind in seinen Texten: Wir sind "he doctors, she doctors, knee doctors und tree doctors". Newman schreibt nicht nur mit zutreffender Ironie, er schreibt auch mit viel Herz, und wenn der Zuhörer beim "wandering boy" einen Kloss im Hals verspürt, dann scheint es ihm beim Schreiben ähnlich ergangen zu sein: "And then I wrote the song. And it came hard. I was chocking up when I was writing the thing - anything that makes you cry must be something to do with yourself.» Also: Im Ops trinken wir ja kein Coke [2], und so eignen sich Randy Newmans hintergründige Texte und die stilvermischende Musik hervorragend. Mit Newmans Ironie behaupte ich: Man bemängelt heute, dass «life» zuwenig Platz hat wegen "work». So haben wir «life» während «work» - einfache Geschichten von einfachen Leuten, einfach vorgetragen. Such is life!

\section{Literatur}

1 Fancourt D, Burton TM, Williamon A. The razor's edge: Australian rock music impairs men's function when pretending to be a surgeon. Med J Aust 2016;205(11):515-8.

2 Randy Newman explains every song on his new album Dark Matter by Ryan Dombal. Pitchfork August 4, 2017. 